\section{U.S. Ueparment of Commerce}

National Bureau

of Standards

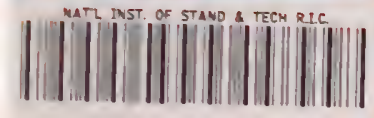
Al1104 55147?
NBSIR 79-1734

\section{Guide to Technical Services and Information Sources for ADP Managers and Users}

Institute for Computer

Sciences and

Technology

April 1979

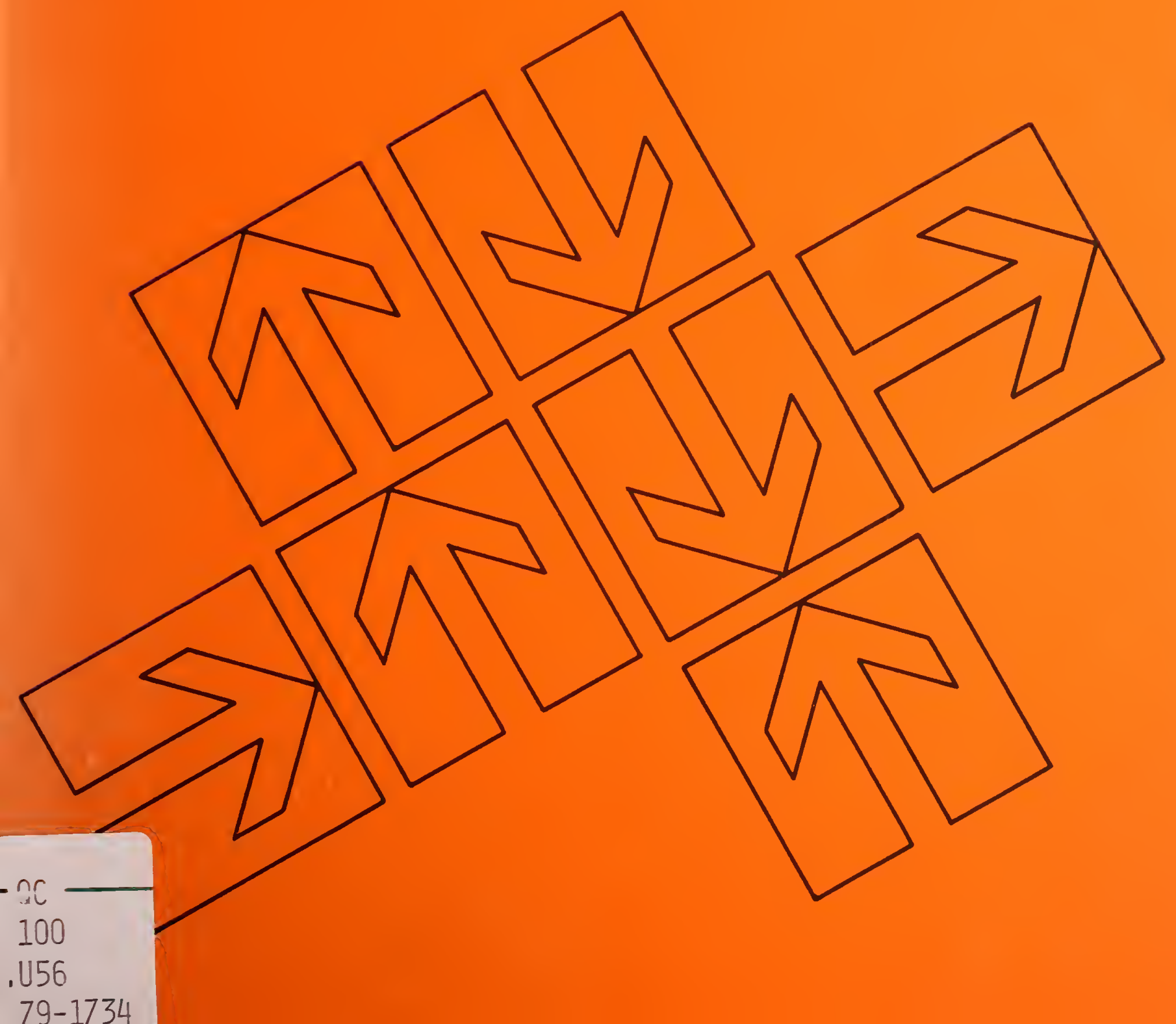





\section{FOREWORD}

During the past year, the President's Reorganization Project for Federal Data Processing was initiated and organized by the Office of Management and Budget (OMB) to study how the Federal Government acquires, manages and uses data processing technology. While this study was chiefly directed toward the broad policy issues related to Federal data processing, specific needs of the Federal ADP community were also addressed.

This guide was developed to fill one such need identified by the Reorganization Study and by OMB -- a single document containing information about the technical services and resources available to Federal ADP managers and users. Included here are brief descriptions of the services and the names, addresses and phone numbers of the agencies providing the services.

We gratefully acknowledge the assistance we received in preparing this guide from the many Federal agency staff members who reviewed it and offered constructive suggestions. We especially thank $\mathrm{Mr}$. Walter W. Haase, Deputy Associate Director for Information Systems Policy, OMB, for his support and interest in this publication.

To enable us to keep the information in the guide current, we invite agencies to let us know about organizational and functional changes. Suggestions for additional entries are also very welcome.

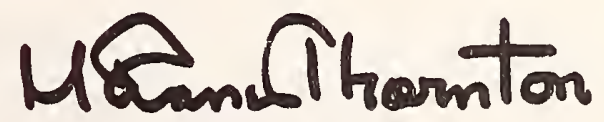

M. Zane Thornton

Acting Director

Institute for Computer

Sciences and Technology 



\title{
CONTENTS
}

\begin{abstract}
CONTENTS
FOREWORD

AGENCIES PROVIDING ADP TECHNICAL SERVICES
\end{abstract}

Page

AND INFORMATION

i i i

INTRODUCTION

vii

TECHNICAL SERVICES AND INFORMATION SOURCES

ix

1. ADP Technical Assistance and Reports

2. ADP Equipment Inventory 2

3. Communications Equipment Inventory 2

4. Directories of Information Systems 3

5. Magnetic Media 5

5.1 Care and Handling of Computer Tape 5

5.2 Magnetic Media Calibration Services 5

5.3 Magnetic Media Standard Reference Materials 6

6. Management Control of ADP Resources 7

7. Management of Records and Information Services 8

8. Performance Evaluation 9

9. Policies and Guidelines on ADP 10

10. Procurement and Management of ADP and Related 11 Services

11. Publications 
12. Security and Privacy 15

13. Simulation and Modelling 15

14. Software and Data Files 15

15. Standards 18

$\begin{array}{lll}15.1 & \text { ADP Standards } & 18\end{array}$

15.2 Data Communication Standards 19

15.3 Language Validation 20

15.4 Magnetic Media Standards 22

15.5 Validation of Encryption Devices 22

16. Training 23

17. User and Special Interest Groups 25

$\begin{array}{ll}\text { APPENDICES } & 27\end{array}$

A. Policies and Guidelines on ADP A-1

B. Federal Information Processing Standards B-1

C. Federal Telecommunication Standards C-1

D. Document Sources D-1

E. GSA Sharing Exchanges E-1

F. GSA Sharing Exchange Locations F-1

G. GSA Regional Offices G-1 


\section{Page}

Computer Performance Evaluation Users Group (CPEUG)

17. User and Special Interest Groups

Computer Software Management and Information Center (COSMIC) 14. Software and Data Files

Department of Defense Computer Institute (DODCI)

16. Training

Federal ADP Users Group (FADPUG)

17. User and Special Interest Groups

Federal Compiler Testing Service (FCTC)

15.3 Language Validation

Federal Computer Performance Evaluation and Simulation

Center (FEDSIM)

8. Performance Evaluation

13. Simulation and Modelling

Federal Software Exchange Center (FSEC)

14. Software and Data Files

General Accounting Office (GAO)

6. Management Control of ADP Resources

General Services Administration (GSA)

2. ADP Equipment Inventory

3. Communications Equipment Inventory

5. Magnetic Media Care and Handling

7. Management of Records and Information Services

10. Procurement and Management of ADP and Related Services

14. Software and Data Files

15.3 Language Validation

Government Printing Office (GPO)

11. Publications

Graduate School, Department of Agriculture

16. Training 
Page 2

$\underline{\text { Page }}$

Interagency Committee on Automatic Data Processing

17. User and Special Interest Groups

National Archives and Records Service (NARS)

7. Management of Records and Information Services

8
24

16. Training

National Bureau of Standards (NBS)

1. ADP Technical Assistance and Reports

15.1 ADP Standards

15.3 Language Validation

5.2 Magnetic Media Calibration Services

5.3 Magnetic Media Standard Reference Materials

15.5 Validation of Encryption Devices

National Communications System (NCS)

15.2 Data Communication Standards

19

National Energy Software Center (NESC)

14. Software and Data Files

National Technical Information Service (NTIS)

11. Publications

13

14. Software and Data Files

Office of Management and Budget (OMB)

9. Policies and Guidelines on ADP

Office of Personnel Management (OPM)

16. Training 


\section{INTRODUCTION}

This guide provides a quick reference to Government resources available to ADP managers and users in Federal agencies. The emphasis is on where to find the technical and training services, information sources, policies and standards that help agencies use computer technology more effectively and efficiently.

The subject areas covered by this guide are listed in the Table of contents. The names, addresses and telephone numbers of the agencies providing the services and brief descriptions of the services are given. The Appendix lists basic reference documents, document sources and locations of GSA Regional Offices and Sharing Exchanges.

In addition to these resources, ADP planning, management and support functions are usually coordinated through a central administrative office in the individual agencies and departments. Also other resources such as journals, periodicals, professional societies, schools, universities, user groups, seminars and conferences offer useful ideas and information about computer technology.

Institute for Computer

Sciences and Technology

National Bureau of Standards April 1979 



\section{ADP Techical Assistance and Reports}

National Bureau of Standards (NBS)

Institute for Computer Sciences and Technology (ICST) Washington, D. C. 20234

Telephone: Programming Science and Technology: (301) 921-3531 Computer Systems Engineering: Publications Lists:

Answers inquiries and provides technical advice and assistance in the selection, procurement and application of computer technology. A limited number of projects such as feasibility studies, systems design, evaluation of vendor proposals for new systems, monitoring of systems development, advice on computer security and risk assessment are accepted on a reimbursable basis.

The criteria for the selection of projects include compatibility with ICST programs in standards development and computer science research and the need for the special expertise of ICST. Additionally, projects can be accepted only if placement with private sector organizations would result in conflicts of interest, excessive delays or excessive costs to the government.

ICST studies and prepares special reports in areas such as security and privacy, computer networks, data base systems, data communications, performance evaluation, statistical data on Federal computers, programming languages, and data codes. These publications may be purchased through the Government Printing Office and the National Technical Information Service (see Publications). Publications lists with ordering information are available from the above address. 
2. ADP Equipment Inventory

General Services Administration (GSA)

virector, CPM

18th and F Streets, N.W.

Washington, D.C. 20405

Telephone: (202) 566-1544

Prepares reports on the Government's inventory of ADP equipment and compiles information about ADP utilization, functional use, manpower, and cost. Publishes annually Automatic Data Processing Equipment Inventory in the U.S. Government and Automatic Data Processing Activities Summary in the U.S. Government (available from the Federal Supply Service and from the Government Printing office).

Also prepares reports tailored to user requirements. Magnetic tapes are available. Output provided to Federal Government users without reimbursement (within limitations).

3. Communications Equipment Inventory

General Services Administration (GSA)

Director, CPM

18th and F Streets, N.W.

Washington, D.C. 20405

Telephone: (202) 566-1544

Collects information about circuits and equipment used for data, facsimile, and record telecommunications for all executive civilian agencies. Reports and summaries are made available to Federal Government users. 
Since compilations of Federal Government information sources have been undertaken by other organizations, this guide does not 1 ist individually the many libraries, resource centers and other information centers providing data on ADP. The following publications are examples of directories providing this kind of assistance.

A Directory of Information Resources in the United States Federal Government (1974)

Compiled by the Science and Technology Division, National Referral Center, U. S. Library of Congress. Includes descriptions of information services, publications and telephone numbers for contacts in agencies. Subject index includes references to computer programs, computer systems hardware, computer simulation. Available from Superintendent of Documents, Government Printing Office, Washington, D. C. 20402, Stock No. 030-000-00067-6. Price \$4.25. (See Publications)

Federal Information Sources and Systems (1976)

A directory issued by the Comptroller Genera1. Describes approximately 1,400 Federal sources and systems maintained by 91 agencies, which contain fiscal, budgeting and program related information. Subject index includes references to computer networks, computers, computer sciences, computer standards. Available from Government Printing Office, Stock No. 020-000-00152-6. Price $\$ 6.75$. (See Publications.) 

(1978)

Directory of information sources in the DDC Referral Data Bank. Identifies specialized scientific and technical information resources that will serve the defense community in their fields of expertise. Includes information sources operated or supported by the Department of Defense and other Federal Government agencies; information analys is centers; other information centers; specialized libraries; information exchanges and information offices; data banks; depositories; laboratories; testing directorates; and other research faci1ities. Subject index includes references to computer applications, computer aided instruction, computer program documentation, computer programming, computer programs, computer sciences, computerized simulation, computers. Available from National Technical Information Service, 5285 Port Royal Road, Springfield, Virginia 22161. $\$ 13.25$ for hard copy, $\$ 3.00$ for microform. Stock Number is AD-A055700. (See Publications.)

Some agencies publish directories of their automated data processing systems. Two examples are:

Directory of Automatic Data Processing Systems in the Public Health Service, Department of Health, Education and Welfare, Office of Assistant Secretary for Health.

Data Systems Catalog and Automated Data Processing Systems Catalog, Department of Defense, Office of Assistant Secretary of Defense (Comptroller). 
5. Magnetic Media

\subsection{Care and Handling of Computer Tape}

Agency Services at GSA Regional Offices (See Appendix for addresses and telephone numbers)

General Services Administration (GSA)

Automated Data and Telecommunications Service

Office of Policy and Planning

Washington, D. C. 20405

Telephone: (202) 566-0202

Provides assistance regarding guidelines on care and handling of computer tape (Subpart 101-36-.12 of Federal Property Management Regulations).

\subsection{Magnetic Media Calibration Services}

National Bureau of Standards (NBS)

Institute for Computer Sciences and Technology (ICST)

B212 Technology

Washington, D. C. 20234

Telephone: (301) 921-3723

Magnetic media standards are used by GSA to test and certify magnetic media for Federal procurement and by industry for quality control in the manufacture of magnetic media. The following services are provided:

- Low density disk calibration. The calibration is performed on Track 000 at $0.625 \mathrm{MHz}$ and on Track 200 at both $0.625 \mathrm{MHz}$ and at $1.25 \mathrm{MHz}$. Cost of service is $\$ 365$.

- Medium density disk calibration service. The calibration is performed with an amplitude type test head on Tracks 000 and 200 at $0.625 \mathrm{MHz}$. Calibration is also performed with a data type test head on Track 200 at both 1.25 and $2.5 \mathrm{MHz}$. Cost of service $\$ 365$.

- High density disk calibration services. The calibration is performed with a high density data head. It is performed on Tracks 000 and 410 at both $1.6 \mathrm{MHz}$ and $3.2 \mathrm{MHz}$. Cost of service is $\$ 365$. 


\subsection{Magnetic Media Standard Reference Materials}

National Bureau of Standards (NBS)

Office of Standard Reference Materials

Room B-311, Chemistry Building

Washington, D. C. 20234

Telephone: (301) 921-2045

Offers the following standard reference materials (SRM's):

- Secondary Standard Magnetic Tape (Computer Amplitude Reference) SRM 3200. This is unrecorded $12.7 \mathrm{~mm}$ computer tape which is calibrated at four densities: $200,800,1600$, and 3200 frpi. Cost is $\$ 787$.

- Secondary Magnetic Tape Cassette (Computer Amplitude Reference) SRM 1600 . This is an unrecorded $3.8 \mathrm{~mm}$ digital cassette which is calibrated at 1600 frpi. cost is $\$ 165$.

- Secondary Standard Magnetic Tape Cartridge (Computer Amplitude Reference) SRM 3216. This is an unrecorded $6.3 \mathrm{~mm}$ digital cartridge which is calibrated at 3200 frpi. Cost (approximately) $\$ 212$. 
General Accounting Office (GAO)

Financial and General Management

Studies Division

441 G Street, N. W.

Washington, D. C. 20548

Telephone: Associate Director for Automatic Data Processing: (202) 275-5044

Reports Distribution:

(202) 275-6241

Conducts independent audits and investigations of executive branch agencies, reports its findings, and recommends changes in laws, policies, methods, or procedures. A principal purpose of GAO inquiries is to assess the effectiveness of management control in Federal agencies. Issues various reports on Federal data processing and telecommunications acquisition, management, and use. Listed below are some reports which may be of special interest. A more complete list of GAO reports and other related documents issued since 1965 can be found in OMB's An Annotated Bibliography of Laws, Policies, Regulations, and Other Documents Pertaining to the Management of Federal Data Processing and Related Telecommunications Activities (See Appendix A).

- Guidelines for Accounting for Automatic Data Processing Costs, 1978. Available from Government Printing Office, Stock No. 020-000-00152-3. (See Pub7ications)

- Management Guidelines for Cost Accounting and Cost Control for Automatic Data Processing Activities and Systems, September 17, 1975. (Available from GA0)

- Audit Guide for Reliability Assessment of Controls in Computerized Systems (Financial Statement Audits) May 1978, FGMSD-No. 16-S/P '78. (Available from GAO)

- Audit Guide for Accessing Reliability of Computer Output, May 1978, FGMSD-No. 17-S/P 178. (Available from GA0)

- Guide for Evaluating Automated Systems, March 1977 (Exposure Draft). (Available from GAO)

- Lessons Learned About Acquiring Financial Management and Other Information Systems, August 1976. Available from Government Printing Office, Stock No. 020-000-00138-1. (See Publications) 
7. Management of Records and Information Services

Office of Records Management

National Archives and Records Service (NARS)

Washington, D. C. 20408

Telephone: (202) 376-8817

Provides technical assistance to help agencies design and implement improved records and information management systems. Trains agencies' managers, management analysts, and others having records and information management responsibilities. Provides training and technical assistance in the proper use of the technology of information. This includes source data automation techniques, microfilm (including computer output microform), word processing, and computerized records systems. Costs are reimbursable.

Office of Federal Records Centers

National Archives and Records Service (NARS)

Washington, D. C. 20408

Telephone: (202) 724-1614

Conducts feasiblity surveys, makes format recommendations and cost proposals, and produces finished microfilm for Federal agencies on a reimbursable basis. The capability to provide such services is available in Federal Archives and Records Centers throught the United States. Information on fees and facilities for microfilming services are published in GSA Bulletins, FPMR "B" series and in the current FSS schedule FSC 67, Part IV Section B. Agencies in the Washington, D. C. area can use the extensive microfilm facilities of the Washington National Records Center.

Assists agencies in developing files maintenance and classification systems and in preparing records disposition schedules. Conducts workshops and other technical assistance traning. Some services are provided on a cost reimbursable basis; others which may be in the interest of the Government as a whole, or of the National Archives and Records Service, are provided at no charge. Further information is available from the Office of Federal Records Centers. 


\section{Performance Evaluation}

Department of the Air Force

Federal Computer Performance Evaluation and Simulation

Center (FEDSIM)

Washington, D. C. 20330

Telephone: (202) 274-8067

Primary source for technical assistance, support, and services for the simulation, analysis, and performance evaluation of Federal Government computer systems. Procedures for reimbursement and for authorizations to procure services from commercial sources are detailed in FPMR 101-36.14.

Services include: studies to determine the kind of computer an agency might require for a new ADP system; how an existing computer can be upgraded to absorb a new workload; how system performance can be improved; how present computer resources are being used; studies of agency workload for selection of benchmark programs to be used in evaluating vendor porposals; reviews of data processing installations to help data center managers evaluate the efficiency of their operational procedures; studies and evaluation of hardware and software performance; assistance in setting up agency performance evaluation activities; training staff on use of performance evaluation and modelling techniques; system communications studies. 
Public Law 89-306 (the Brooks Act), dated October 30, 1965, provides for the economic and efficient purchase, lease, maintenance, operation, and utilization of automatic data processing equipment by Federal departments and agencies. It amends the Federal Property and Administrative Services Act of 1949 (63 Stat. 377) giving the General Services Administration responsibility for the procurement, utilization and disposition of automatic data processing equipment; the Department of Commerce responsibility for developing data processing standards, for providing agencies with advisory services, and for conducting computer science research; the Office of Management and Budget responsibility for policy and fiscal control over ADP activities.

Policy and procedural guidelines related to agency responsibilities for ADP, data transmission, computer communications interface, and to data element standards are contained in Federal Information Processing Standards Publications 12-2 and 23. See Appendix B.

Policies and procedures related to ADP procurement and management are contained in the Federal Property Management Regulations (FPMR) and the Federal Procurement Regulations (FPR) available through GSA. See Appendix A.

OMB Circulars concerning ADP policy, privacy and security are available from the Office of Management and Budget, 395-4660.

See Appendix D for document sources. 
10. Procurement and Management of ADP and Related Services

General Services Administration (GSA)

Automated Data and Telecommunications Service

Washington, D. C. 20405

Telephone: (202) 566-1126

GSA Agency Services at Regional offices (See Appendix for addresses and telephone numbers)

Issues, policies, procedures and guidelines concerning Government-wide procurement and management of ADP equipment and related services. Assists agencies in the application of the policies, procedures and guidelines.

Some of the services include:

ADP Sharing Program: Nation-wide system of information clearinghouses through which ADP services may be requested or made available to Federal agencies. The program operates through regional Sharing Exchanges which serve as central points of contacts for information, advice and service on available ADP resources. See Appendix for locations and addresses of Sharing Exchanges. Information provided without cost to agency on available resources such as ADP equipment, software support and personnel services. Agencies then make their own arrangements for services. ADP Sharegrams issued by regional offices to announce availability of specific services.

Federal Data Processing Centers: Operated either by GSA or by another agency under a delegation of authority from GSA to perform data processing and related services. Services vary to include machine time, software, data conversion, technical consulting, programming and systems analysis. Costs are reimbursable.

Reutilization of Data Processing Equipment and Supplies: Arranges for transfers and use of ADP equipment that is no longer required for the purpose for which it had been acquired. Collects information about ADP equipment that is available and distributes an Availability List to inform Federal agencies of available excess and exchange/sale equipment. Requests to be placed on mailing list for the Availability List should be made to General Services Administration (CDSDE), Washington, D. C. 20405. 
Procurement: Reviews requirements for $A D P$ and tries to meet these requirements through utilization of existing inventory of equipment, by combining agency resources, or by satisfying requirements through GSA-provided systems or services. If unable to meet agency requirements with existing or planned resources, conducts procurements or gives agency authority to conduct procurement in accordance with existing policies and regulations.

Standards Compliance: Reviews ADP/telecommunications procurements to assure that proper reference to standards is included under mandatory requirements of the solicitation. Also reviews agency requests for ADP service for standards compliance.

Management and Control of Computer Rooms: Issues general criteria for use by agencies in maintaining the computer room and assists agencies in carrying out the guidelines. See FPMR Subpart 101-36.7.

Systems Studies: Assists agencies in conducting data communications and system planning studies before procuring data processing equipment. Advises on collocation and consolidation of automatic data processing facilities. 
The prices given for publications in this guide are subject to change, and should be checked with the Government Printing Office (GPO) or the National Technical Information Service (NTIS) before orders are placed.

Superintendent of Documents Government Printing Office (GPO) Washington, D. C. 20402

Order Desk: (202) 783-3238

Stocks and sells Government-produced reports on computer science and technology. Requests to receive monthly notice of selected U. G. Government publications and/or to receive special announcements about computer science and technology publications (specify list $\mathrm{N} 503$ for the latter) may be submitted to above address. Also information about a monthly catalog of all GPO publications can be obtained from above address.

National Technical Information Service (NTIS)

5285 Port Royal Road

Springfield, Virginia 22161

Telephone: (202) 724-3382

Stocks and sells U. S. and foreign government-sponsored research, development, and engineering reports and other analyses prepared by national and local government agencies, their contractors or grantees, or by Special Technology Groups. Also a source for Federally-generated machine processable data files and manager of the Federal Software Exchange Center.

Prepares a weekly government abstract newsletter that covers computers, control and information theory. Subjects included are: computer hardware, computer software; control systems and control theory; information processing standards; information theory; pattern recognition. Subscription cost is $\$ 75$ for one year. Newsletter contains summaries of research studies and reports.

Prepares custom searches of entire collection and has available completed searches in particular subject areas. Inquire about costs at above address. 
Sells Federal Information Processing Standards (FIPS) publications by the copy and by standing order whereby new and revised FIPS PUBS, along with any change notices and associated industry standards issued during the year, are sent to subscribers automatically. Price is $\$ 40$ annually. A complete set of all FIPS in effect (FIPS Set 76) is $\$ 120$. (See Appendix $B$ for list of FIPS in effect.)

See ADP Technical Assistance and Reports for information about NBS computer-related publications. 
For advice on encryption and applications, risk analysis, security safeguards, systems planning for security - see ADP Technical Assistance and Reports.

For security and privacy considerations in the procurement and management of $A D P$ and telecommunications equipment, software, maintenance and services - see the following documents:
Policy Guidance and Standards (See Appendix A) OMB Circulars A-108 and A-71
FPMR Subpart 101-35.17
FIPS $31,38,41,46,48$
Proposed Federal Telecommunication Standards 1026 and 1027
For Validation of Encryption Devices - See Standards

13. Simulation and Modelling

See Federal Computer Performance Evaluation and Simulation Center (Performance Evaluation)

14. Software and Data Files

Federal Software Exchange Center (FSEC)

5285 Port Royal Road

Springfield, Virginia 22161

Telephone: (703) 557-4655

Collects information about common-use software and publishes a catalog with quarterly updates containing abstracts of available software. Catalog may be ordered on an annua? subscription basis for $\$ 75$ from the above address. Federal agencies may request software and related documentation through the FSEC. Minimal charges are made for magnetic tapes and documentation.

Program is carried out by GSA to promote interagency sharing of common-use computer programs and systems. Agencies are required to review software to identify programs or systems that would be of use to other agencies.

Abstracts of the software are submitted to the FSEC on SF 185, Federal Information Processing Standard Software Summary. Summaries include information about the sofiware's purpose and other significant factors such as processing mode computer manufacturer and model, operating system, programming language, input/output media, memory requirements. 
National Technical Information Service (NTIS)

5285 Port Royal Road

Springfield, Virginia 22161

Telephone: (202) 724-3382

Has available for sale or lease to the public about 800 data files and/or related software for business and scientific applications. The software covers both general applications such as report generators and language translators and specific applications such as payroll, personnel, accounting and inventory systems. The NTIS Directory of Computerized Data Files, Software and Related Technical Reports (NTISSR-7502/PTC) is available from the above address. It contains information about ordering individual items from either NTIS or originating agencies.

Computer Software Management and Information Center (COSMIC)

112 Barrow Hall

University of Georgia

Athens, Georgia 30602

Telephone: (404) 542-3265

COSMIC is operated by the University of Georgia under contract to the National Aeronautics and Space Administration (NASA) in support of the NASA Technology Utilization program. As such, computer programs and their documentation developed by NASA or NASA contractors, are made available to the general public. Recent software available from COSMIC is announced in the general quarterly journal, Computer Program Abstracts, available to subscribers for $\$ 6.50$ a year total or $\$ 1.65$ for a single copy from the Superintendent of Documents, U. S. Government Printing Office, Washington, D. C. 20402.

National Energy Software Center (NESC)

Argonne National Laboratory

9700 South Cass Avenue

Argonne, Illinois 60439

Telephone: (312) 972-7250

Operates a computer software and data exchange and information center under Department of Energy and Nuclear Regulatory Commission funding. Collects, reviews, tests, maintains, and distributes a library of software developed by DOE offices and contractors. Provides other software information services such as publication of abstracts describing the collection 
and summaries of ongoing software development efforts. Responsible for communication and exchange arrangements with other U.S. and foreign software centers and the coordination of non-government software acquisition for DOE.

Information and distribution services are provided to registered organizations that either qualify for free services or that pay a subscription fee. Organizations for which the fee is waived include DOE and NRC offices and contractors, and agencies with whom reciprocal agreements are arranged. 
15. Standards

15.1 ADP Standards

National Bureau of Standards (NBS)

Institute for Computer Sciences and Technology (ICST)

Washington, D.C. 20234

Telephone: (301) 921-3157

Analyzes the need for ADP standards, carries out necessary research for standards development, develops standards, assesses impacts and benefits, and monitors standards implementation. The Secretary of Commerce on behalf of the President approves ADP standards for use in procurement and utilization of computer systems and services by Federal departments and agencies. ADP standards cover hardware, software, data and applications.

Approved ADP standards and guidelines are published in Federal Information Processing Standards Publications (FIPS PUBS) which are available from the National Technical Information Service (NTIS), 5285 Port Royal Road, Springfield, Virginia 22161. (See Publications, NTIS, for ordering information, and Appendix B for a complete list of FIPS in effect.)

FIPS are applicable to a11 Federal agencies unless the agencies are otherwise excepted. Waiver procedures and applicability provisions are included in the individual FIPS PUBS. GSA issues regulations to implement FIPS in the procurement of equipment and services.

ICST participates in and coordinates the Federal participation in ADP standards development by voluntary industry organizations. FIPS PUBS include voluntary industry standards when these are adopted for Federal use.

Voluntary ADP standards are developed under the auspices of the American National Standards Institute (ANSI), 1430 Broadway, New York, N.Y. 10018, and its committee for Computers and Information Processing $(X-3)$. The Computer and Business Equipment Manufacturers Association (CBEMA) 1828 L Street, NW, Washington, D.C. 20036 is the secretariat for the $X-3$ committee.

ANSI is the national organization that coordinates the development, approval, and promulgation of voluntary national standards: Technical societies, trade associations, and individual companies make up the membership 
of ANSI. ANSI represents U.S. viewpoints in international standards development through the International Organization of Standardization (ISO) and the International Electrotechnical Commission (IEC) a branch of ISO that is concerned with electronics and electrical equipment.

\subsection{Data Communication Standards}

Office of the Manager

National Communications System (NCS-TS) Washington, D.C. 20305

Develops and recommends Federal Telecommunication Standards for operational compatibility among functionally similar networks of the NCS. In concert with NBS, develops and recommends joint Federal Telecommunication/Federal Information Processing Standards (FTS/FIPS) for data transmission and the computercommunication interface. NBS and NCS have agreed to the exclusive and mutual responsibilities of their respective organizations for the development of Federal Standards related to data transmission and the computer-communications interface.

The Federal Telecommunication Standards Committee (FTSC), which oversees the development of Federal Telecommunication Standards, is comprised of representatives of the NCS constituent agencies*, the Department of Health, Education and Welfare, the National Security Agency, the Library of Congress, and the National Bureau of Standards. The NCS office of Technology and Standards coordinates these activities within the Government, and with national and international standards development bodies.

The General Services Administration (GSA) is responsible for the Federal Standards Program under the Federal Property and Administrative Services Act of 1949 , as amended. The GSA also implements Federal Information Processing and Telecommunication Standards in solicitation documents (as authorized in Subpart 101-36.13 of the Federal Property Management Regulations). Eleven Federal Telecommunication Standards (FTS) have been published; five of these are joint FTS/FIPS. (See Appendix C)

*Department of Defense, Department of State, General Services Administration, Federal Aviation Administration, National Aeronautics and Space Administration, Central Intelligence Agency, Department of Commerce, Department of Energy, Department of the Interior, and the U.S. International Communication Agency. 
Inquiries concerning Federal Telecommunications Standards, including data communication standards, may be addressed to:

Office of the Manager

National Communications System

Office of Technology and Standards

Washington, D.C. 20304

Telephone: (202) 692-2124

Inquiries concerning joint standards may also be addressed to the National Bureau of Standards. See Section on ADP Standards above.

\subsection{Language Validation}

The National Bureau of Standards is responsible for the development and maintenance of ADP programming language standards. A Federal Information Processing Standard is in effect only for COBOL; however, test programs are available for both MinimaT BASIC and FORTRAN.

\section{BASIC}

National Bureau of Standards (NBS)

Institute for Computer. Sciences and Technology (ICST)

A-265 Technology

Washington, D.C. 20234

Telephone: (301) 921-3491

Answers inquiries concerning test programs for Minimal BASIC. Makes available Minimal BASIC test programs on magnetic tape and Minimal Basic Test Programs (Version 1) User's Manual (NBSIR 78-1420-1,2,3,4).

$\underline{\mathrm{COBOL}}$

Federal Compiler Testing Center. (FCTC)

Automated Data and Telecommunications Service General Services Administration

Washington, D. C. 20406

Telephone: (202) 557-7806

Handles requests for validation of COBOL compilers and answers inquiries about validation test procedures, interpretation of results and reimbursement policies. 
A11 COBOL compilers brought into the Federal inventory must implement one of the four levels of the revised Federal COBOL Standards as defined in Federal Information Processing Standard (FIPS PUB) 21-1 (COBOL 74). The National Bureau of Standards, which has the responsibility for the development and maintenance of Federal ADP standards, has delegated to the FCTC the responsibility for the operation of a governmentwide COBOL compiler testing service.

Validation services are provided on a reimbursable basis to vendors and to Government agencies. Cost estimates are provided. Test facilities must be furnished by the requestor. FCTC prepares Validation Summary Reports covering the degree to which compilers implement the expressions and functions specified in the COBOL standard.

Questions about the meaning of COBOL language specifications should be referred to:

Chairman, Federal COBOL Interpretations Committee Institute for Computer Sciences and Technology (ICST) National Bureau of Standards (NBS) Washington, D.C. 20234

Telephone: (301) 921-3491

Magnetic tapes containing the COBOL Compiler Validation System (CCVS) and a user's guide may be obtained from the National Technical Information Service, Springfield, Virginia 22151. Telephone: (703) 557-4650. (See Software and Data Files, NTIS.)

There is no officially recognized process for testing FORTRAN compilers in the Federal Government.

FORTRAN Test Programs developed by the National Bureau of Standards are available from the National Technical Information Service, Springfield, Virginia 22161 on magnetic tapes. Stock number is COM-75-10182/4CP and the price is $\$ 400$. (See Software and Data Files, NTIS.)

The associated user's guide, NBS FORTRAN Test Programs, is published in three volumes. (NBS Special Publication 399-1, 2,3 , October 1974). Order from the Government Printing Office as C13.10:399-1, C13.10:399-2, and C13,10:399-3 for $\$ 1.10, \$ 2.65$, and $\$ 1.05$ respectively. (See Publications.) 
15.4 Magnetic Media Standard

See Magnetic Media

15.5 Validation of Encryption Devices

National Bureau of Standards (NBS)

Institute for Computer Sciences and Technology (ICST)

A-247 Technology

Washington, D.C. 20234

Telephone: (301) 927-3531

Validates hardware implementations of the NBS Data Encryption Standard (FIPS PUB 46) for conformance with the standard. Issues a certificate of validation for devices that are successfully tested. Devices certified by the manufacturer as identical to the validated device may be procured and used by Government agencies . 
16. Training

Office of Personnel Management (OPM)

Workforce Effectiveness and Development Group

Washington, D.C. 20415

Telephone: (202) 632-5650

Offers courses through its ADP Management Training Center for: ADP User Education (introductory courses and specialized seminars in ADP for Government employees at all levels); information about the computer, its applications, and usermanagement responsibilities; computer specialist training programs for people involved in all levels of data processing (includes programming, systems analysis and design); Upward Mobility Training - entry-level ADP skills in operator training, programmer training and card punch operator training. Also tailors training programs to meet individual agency requirements. Training services are provided to agencies on a reimbursable basis either through tuition charges or interagency agreement.

Department of Defense Computer Institute (DODCI) Building 175, Washington Navy Yard

Washington, D.C. 20374

Telephone: (202) 433-3391

Conducts ADP courses primarily for military and civilian managers within the Department of Defense. Federal (non-DOD) state, and local Government agencies may nominate personnel on a space available basis. Subject areas include information management for senior executives, computer orientation for intermediate executives, introduction to computer technology, computer support for WWMCCS, ADP resource acquisition, computer performance evaluation, information system analysis and design, computer system security, Privacy Act and information systems, introduction to teleprocessing, and ADP project management. ADP managerial advisory services are available on a limited basis. Publishes catalog giving location and scope of ADP courses available at individual service schools and at local DOD installations. 
Graduate School, U.S. Department of Agriculture

Room 1031

South Agriculture Building

Washington, D.C. 20250

Telephone: (202) 447-7124 (daytime program information)

(202) 447-3039 (evening program information)

Offers evening and daytime training in computer science. The evening program is conducted on a quarter system, and courses are ten weeks in length. Cost is $\$ 19$ per credit hour, and additional fees for computer time may be charged. Daytime courses are conducted in an intensive seminar format for 3-5 days, and fees vary. In-house training may be arranged on request. Courses are offered at beginning through advanced levels in areas including operations and hardware, programming, systems analysis and design, and computer management.

Office of Records Management

National Archives and Records Service (NARS)

Washington, D. C. 20408

.Telephone: (202) 376-8817

Annually schedules and presents a variety of interagency training courses that help Federal agencies achieve proficiency in the latest principles and techniques of records and informational management. Principles are presented in practical terms that are directly applicable to operational needs. Instruction and discussion are keyed to the experiences and responsibilities of the participants. An annual schedule of records and information management workshops is distributed directly to the agencies.

In addition to the scheduled interagency training courses, other training activities are developed to meet the special needs of individual agencies. Such training is usually conducted in the agencies and incorporates an agency's unique environmental and program elements. 
17. User and Special Interest Groups

Interagency Committee on Automatic Data Processing

Executive Secretary: Glenna Hogan

General Services Administration ADTS/CP

18th and F Street, NW Room 2239

Washington, D.C. 20405

Telephone: (202) 566-0202

Composed of senior ADP staff members representing each Federal agency. Holds monthly meetings for exchange of information on management and technological developments; forum for discussion of policies and regulations. Sponsors Governmentwide conferences and publishes an annual directory of top ADP people in each agency (available from above address). Sponsors special interest groups for careerdevelopment/training; data administration; planning and policy; project management; users involvement in systems and new technology; computer security; evaluation and review; installation management.

\section{Federal ADP Councils}

Forums for exchange of information on government management and use of ADP resources. Activities focus on sharing and exchange of ideas and techniques, promoting professional development of personnel, developing better communication between ADP installations, and clarifying ADP policies and guidelines.

The following Federal ADP Councils have been established:

Federal Information Processing Council of New England (Region 1)

Federal Information Processing Council of New York (Region 2)

Federal ADP Users Group (Region 3)

Federa 1 ADP Council of Greater Tidewater (Region 3)

Philadelphia ADP Council (Region 3)

ADP Council of the Southeastern States, Inc. (Region 4)

Intergovernmental ADP Council (Region 5)

Dallas-Forth Worth ADP Council (Region 7)

Albuquerque - Santa Fe ADP Council (Region 7)

New Orleans ADP Council (Region 7)

San Antonio ADP Council (Region 7)

Intergovernmental ADP Council (Region 8)

Federal ADP Council of Northern California (Region 9)

Federal ADP Council of Southern California (Region 9)

Puget Sound ADP Counci] (Region 10) 
For additional information about the activities of these councils, contact the GSA Regional Office (See Appendix G) in which they are located.

Federal ADP Users Group (FADPUG)

For information: David R. Skeen

Telephone: (202) 649-4270

Organization of Federal, state and local employees concerned with effective management and use of Government ADP resources. Acts as the Federal ADP Council for the Capitol Region (Washington, D.C., Maryland, Virginia, Pennsylvania, West Virginia and Delaware.)

Sponsors special interest groups in career development and training; management graphics; privacy and security; ADP procurement; ADP standards; software; user's involvement in systems and new technology; zero-base budgeting and automated data processing.

Computer Performance Evaluation Users Group (CPEUG)

Sponsored by the National Bureau of Standards

Institute for Computer Sciences and Technology

A-265 Technology

Washington, D.C. 20234

Telephone: (301) 921-3485

Forum for computer professionals involved in improving the efficiency and effectiveness of Federal data processing facilities. Holds annual conference and publishes conference proceedings. 


\section{APPENDICES}

Page No.
A. Policies and Guidelines on ADP ......... A-1
B. Federal Information Processing Standards ..... B-1
C. Federal Telecommunication Standards ........ C-1
D. Document Sources ............. . D-1
E. GSA Sharing Exchanges ............ . E-1
F. GSA Sharing Exchange Locations .......... . F-1
G. GSA Regional Offices ............ G-1 

Listed here are several of the more important regulations and and policy guidance documents for Federal ADP activities.

A comprehensive compilation of these documents, entitled An Annotated Bibliography of Laws, Policies, Regulations and Other Documents Pertaining to the Management of Federal Data Processing and Related Telecommunications Activities (December 1978) has been issued by the Office of Management and Budget (contact: OMB, Information Systems Policy Division, Washington, D.C. 20503).

\section{Office of Management and Budget Circulars}

- Circular No. A-11, "Preparation and Submission of Budget Estimates," Revised, Transmittal Memorandum No. 48, May 25, 1978.

This is the circular issued every year which gives detailed instructions on the preparation of the Budget Estimates. Section 43 concerns data processing and telecommunications systems. Section 24 requires budget justification for data processing and telecommunications resources based on programmatic need.

- Circular No. A-25, "User Charges," September 23, 1959, Transmittal Memorandum No. 1, October 22, 1963, Transmittal Memorandum No. 2, April 16, 1974.

This circular provides the guidance for determining when services performed by the Federal Government for individuals must be reimbursed. This circular covers such items as patent fees, pilot examinations, passport requests, etc. These policies apply when the Federal Government provides data processing services for individuals.

- Circular No. A-71, "Responsibilities for the Administration and Management of Automatic Data Processing Activities," March 6, 1965. Transmittal Memorandum No. 1, Ju7y 27, 1968: "Security of Federal Automated Information Information Systems." 
This circular sets forth the relationships and responsibilities of the agencies of the Federal Government in regard to the administration and management of data processina. Transmittal Memorandum No. 1 establishes the responsibilities and requirements for a Federal computer security program.

- Circular No. A-73, "Audit of Federal Operations and Programs," March 15, 1978.

This circular sets forth policies to be followed by Federal agencies in the audit of Federal operations and programs.

- Circular No. A-76, "Policies for Acquiring Commercial or Industrial Products and Services for Government Use," Revised, Transmitta 1 Memorandum No. 1, Auqust 30, 1967; Transmittal Memorandum No. 2, October 18, 1976; Transmitta 1 Memorandum No. 3, June 13, 1977.

This circular establishes the policy that private enterprise is the preferred source of supply for commercial or industrial goods and services (including data processina) unless it is significantly more costly or not in the Government's best interest under specific circumstances.

- Circular No. A-90, "Cooperating with State and Local Governments to Coordinate and Improve Information Systems," September 21, 1968; Transmittal Memorandum No. 1, September 7, 1976.

This circular furnishes guidance to Federal agencies for cooperating with and assisting State and local governments in the coordinated development and operation of intergovernmental information systems.

Circular No. A-94, "Discount Rates to be Used in Evaluating Time-Distributed Costs and Benefits," Revised, March 27, 1972.

This circular prescribes a standard discount rate to be used in evaluating the measurable costs and/or benefits of programs or projects when they are distributed over time.

- Circular No. A-108, "Responsibilities for the maintenance of records about individuals by Federal agencies," July 1, 1975; Transmittal Memorandum No. 1, September 30, 1975: Responsibilities for the Maintenance of Records About Individuals by Federal Agencies; Transmittal Memorandum No. 2, March 25, 1976: Reporting Instructions for the Annual Report to the Congress under the Privacy Act of 1974; Transmittal Memorandum No. 3, May 17, 1976: Privacy Act Implementation and Revised Guidance on New Systems Report; Transmittal Memorandum No. 4, 
January 31, 1978: Reporting Instructions for the Annual Report to the Congress.

This circular defines the responsibilities of Federal agencies in implementing the Privacy Act of 1974 (Public Law 93-579, 5 U.S.C. 552a).

- Circular No. A-109, "Major System Acquisitions," Apri1 5, 1976.

This circular describes the policies and procedures to be followed in the acquisition of major systems by the Federal agencies. System, as it is used here, includes, but is not restricted to, data processing. Examples of systems are weapon systems, space mission systems, etc.

- Circular No. A-115, "Zero Base Budgeting," May 5, 1978.

This circular contains Governmentwide zero base budgeting ( $\mathrm{BBB}$ ) concepts and guidelines for the budget cycle and provides the foundation for agency budget submission in accordance with OMB Circular No. A-11. These concepts and guidelines provide a framework for the development of agency ZBB systems.

Federal Procurement Regulations (FPR)

Issued by the General Services Administration to govern the acquisition of items or services required by Federal agencies. The provisions pertaining to data processing are included in Section 1-4: "Special Types and Methods of Procurement." The specific subsections are as follows:

FPR 1-4.11: Procurement and Contracting for Governmentwide ADP Equipment, Software, Maintenance Services, and Supplies

1-4.1100 Scope of Subpart

1-4.1101 Applicability

1-4.1102 Definitions

1-4.1103 Procurement Authority

1-4.1104 Request for Procurement Action

1-4.1105 GSA Action on Procurement Requests

1-4.1106 Federal Agency Responsibilities When Procurement Authority is Delegated by GSA

1-4.1107 Procurement Guidance

$1-4.1108$ Standard Clauses

1-4.1109 Reserved 
The following temporary Federal Procurement Regulations are also in effect:

- Temporary Regulation 46, "Use of Smal1 Purchase Procedures and Schedule Contracts for Automatic Data Processing (ADP) Requirements," effective October 16, 1978.

- Temporary Regulation 47, "Major System Acquisition for Automatic Data Processing and Telecommunications," effective October 16, 1978.

Federal Property Management Regulations (FPMR)

Issued by the General Services Administration to provide specific guidance in the management and operation of equipment and ADP activities. Sections relevant to data processing include:

- FPMR 101-11 Records Management

- FPMR 101-29 Data Communications

- FPMR 101-35 ADP and Telecommunications Management Policy

- FPMR 101-36 ADP Management

- FPMR 101-37 Telecommunications Management 


\section{APPENDIX B}

FEDERAL INFORMATION PROCESSING STANDARDS PUBLICATIONS

(FIPS PUBS)

FIPS PUB

\section{TITLE}

$0 \quad$ General Description of FIPS Register, November 1968

1 Code for Information Interchange, November 1968

2 Perforated Tape Code for Information Interchange, November 1968

3-1 Recorded Magnetic Tape for Information Interchange (800 CPI, NRZI), June 1973

$4 \quad$ Calendar Date, November 1968

5-1 States and Outlying Areas of the U.S., June 1970

6-2 Counties and County Equivalents of the States of the U.S., September 1973

7 Implementation of Code for Information Interchange, March 1969

8-4 Standard Metropolitan Statistical Areas (SMSAs), June 1974

9 Congressional Districts of the U.S., November 1969

10-2 Countries, Dependencies and Areas of Special Sovereignty, March 1977

11-1 Dictionary for Information Processing, September 1977

12-2 Federal Information Processing Standards Index, December 1974

13 Rectangular Holes in 12-Row Punched Cards, October 1971

14 Hollerith Punched Card Code, October 1971

15 Subsets of Standard Code for Information Interchange October 1971

16-1 Bit Sequencing of Code for Information Interchange in SerialBy-Bit Data Transmission, September 1977 
17-1 Character Structure and Character Parity Sense for SerialBy-Bit Data Communication, September 1977

18-1 Character Structure and Character Parity Sense for Paralle1By-Bit Data Communication in Code for Information Interchange, September 1977

19 Guidelines for Registering Data Codes, February 1972

20 Guidelines for Describing Information Interchange Formats, March 1972

21-1 COBOL, December 1975

22-1 Synchronous Signaling Rates Between Data Terminal and Data Communication Equipment, September 1977

23 Objectives and Requirements, February 1973

24 Flowchart Symbols and Their Usage in Information Processing, June 1973

25 Recorded Magnetic Tape for Information Interchange (1600 CPI, $\mathrm{PE})$, June 1973

26 One-Inch Perforated Paper Tape for Information Interchange, June 1973

27 Take-Up Reels for One-Inch Perforated Tape, June 1973

28 Standardization of Data Elements and Representations, June 1973

29 Interpretation Procedures for Federal Standard COBOL, June 1974

30 Software Summary for Describing Computer Programs and Data Systems, June 1974

31 Guidelines for ADP Physical Security and Risk Management, June 1974

32 Optical Character Recognition Character Sets, August 1974

33 Character Set for Handprinting, October 1974

34 Guide for Use of International System of Units (SI) in Federal Information Processing Standards Publications, January 1975 
36 Graphic Representation of Control Characters of ASCII, June 1975

37 Synchronous High Speed Data Signaling Rates Between Data Terminal Equipment and Data Communications Equipment, June 1975

38 Guidelines for Documentation of Computer Programs and Automated Data Systems, February 1976

39 Glossary for Computer Systems Security, February 1976

40 Guideline for Optical Character Recognition Forms, May 1976

41 Computer Security Guidelines for Implementing Privacy Act of 1974, May 1975

42-1 Guidelines for Benchmarking ADP Systems in Competitive Procurement Environment, May 1977

43 Aids for Program COBOL Conversion (FIPS 21 and 21-1), December 1975

44 COBOL Coding Form, September 1976

45 Guide for the Development, Implementation and Maintenance of Standards for the Representation of Computer Processed Data Elements, September 1976

46 Data Encryption Standard, January 1977

47 Federal Standard COBOL Pocket Guide, February 1977

48 Guidelines on Evaluation of Techniques for Automated Personal Identification, April 1977

49 Guideline on Computer Performance Management: An Introduction, May 1977

50 Recorded Magnetic Tape for Information Interchange, 6250 cpi (246 cpmm) Group Coded Recording, February 1978

51 Magnetic Tape Cassettes for Information Interchange $(3.810 \mathrm{~mm}$ [0.150 in] Tape at 32 bpmm [800 bpi], PE), February 1978 
52 Recorded Magnetic Tape Cartridge for Information Interchange, 4 Track, $6.30 \mathrm{~mm}$ (0.125 in) 63 bpmm [1600 bpi] Phase Encoded, July 1978

53 Transmittal Form for Describing Computer Magnetic Tape File Properties, Apri 11978

54 Computer Output Microform Format and Reduction Ratios, July 1978

55 Guideline for Codes for Named Populated Places and Related Entities of the States of the United States, June 1978

56 Guidelines for Managing Multi-Vendor Plug Compatible ADP Systems, September 1978

57 Guideline for the Measurement of Interactive Computer Service Response Time and Turnaround Time, Auqust 1978

58 Representations of Local Time of Day for Information Interchange, February 1979

59 Representations of Universal Time, Local Time Differentials, and United States Time Zone Reference for Information Interchange, February 1979

60 I/0 Channel Interface, February 1979

61 Channel Level Power Control Interface, February 1979

62 Operational Specifications for Magnetic Tape Subsystems, February 1979 


\section{APPENDIX C}

\section{FEDERAL TELECOMMUNICATION STANDARDS}

FED STD 1001 *

FED STD 1002

FED STD 1005

FED STD 1006

FED STD 1010 *

FED STD 1011 *

FED STD 1012 *

FED STD 1013 *

FED STD 1020

FED STD 1030

FED STD 1035
High Speed Synchronous Signaling Rates Between Data Terminal Equipment and Data Circuit Terminating Equipment

Time and Frequency Reference Information

$2400 \mathrm{Bit} / \mathrm{s}$ Modems

$4800 \mathrm{Bit} / \mathrm{s}$ Modems

Bit Sequencing of Code for Information Interchange in Serial-By-Bit Data Transmission

Character Structure and Character Parity Sense for Serial-By-Bit Data Communication

Character Structure and Character Parity Sense for Parallel-By-Bit Data Communication in Code for Information Interchange

Synchronous Signaling Rates Between Data Terminal and Data Communication Equipment

Electrical Characteristics of Unbalanced Voltage Digital Interface Circuits

Electrical Characteristics of Unbalanced Digital Interface Circuits

Single Channel RTTY for Maritime Mobile Applications

The following proposed Federal Standards for the implementation of the Data Encryption Standard (FIPS 46) in Government communication systems are being coordinated within industry and government organizations:

FED STD 1026

Telecommunications: Compatibility Requirements for Use of the Data Encryption Standard (DRAFT)

FED STD 1027

Telecommunications: Security Requirements for Use of the Data Encryption Standard (DRAFT)

*Joint Federal Telecommunication and Federal Information Processing Standards 



\section{APPENDIX D}

\section{DOCUMENT SOURCES}

Document

OMB Circulars

Federal Information Processing Standards

Federal Procurement Regulations

Federal Property Management Regulations

Federal Telecommunication Standards GSA Management Guidance
Source

Office of Administration

Room G-236

New Executive Office Building

76 Jackson Place, NW

Washinạton, D.C. 20503

(202) $395-4660$

National Technical Information Service

5285 Port Royal Road

Springfield, Virainia 22161

(703) $557-4650$

General Services Administration Specification Sales Building 197

Washington Navy Yard Washington, D.C. 20407

(202) 472-2205 



\section{GSA SHARING EXCHANGES}

GSA Region 1, ADP Sharing Exchange, Boston, MA: General Services Administration (CP), John W. McCormack Post Office and Courthouse, Room 817, Boston, MA 02109. Telephone: Commercia1, 617-223-6277; FTS, 223-6277.

GSA Region 2, ADP Sharing Exchange, New York, NY: Genera 1 Services Administration (2CP), 26 Federal Plaza, New York, NY 10017. Telephone: Commercial, 212-264-3631; FTS, 264-3637.

GSA Region 3, ADP Sharing Exchange, Washington, DC: General Services Administration (3CP), 7 th and D Streets, SW., Washington, DC 20407. Telephone: Commercial, 202-472-1638; FTS, 472-1638.

Philadelphia ADP Sharing Exchange, General Services Administration (3CTON), William J. Green, Jr., Federal Building, 600 Arch Street, Room 9400, Philadelphia, PA 19106. Telephone: Commercial, 215-597-7918; FTS, 597-7918.

Tidewater ADP Sharing Exchange, Headquarters 5 th Naval District, Norfolk, VA 23511. Telephone: Commercial, 804-444-7571; FTS, 954-7571; Autovon, 690-7571.

GSA Region 4, ADP Sharing Exchange, Atlanta, GA: General Services Administration (4CP), 1776 Peachtree Street, NW. Atlanta, GA 30309. Telephone: Commercial, 404-881-3456; FTS, 257-3456; Autovon, 588-3591.

GSA Region 5, ADP Sharing Exchange, Chicago, IL: General Services Administration (5CP), 230 South Dearborn Street, Chicago, IL 60604. Telephone: Commercial, 312-886-3820; FTS, 886-3820.

GSA Region 6, ADP Sharing Exchange, Kansas City, MO: General Services Administration (6CP), 1500 East Bannister Road, Kansas City, MO 64131. Telephone: Commercial, 816-926-7540; FTS, 926-7540; Autovon, 465-7540.

GSA Region 7, ADP Sharing Exchange, Fort Worth, TX: General Services Administation (7CP), 819 Taylor Street, Forth Worth, TX 76102. Telephone: Commercia1, 817-334-3684; FTS, 334-3684.

GSA Region 8, ADP Sharing Exchange, Denver, CO: General Services Administration (8CP), Building 41, Denver Federal Center, Denver, CO 80225. Telephone: Commercia1, 303-234-2466; FTS, 234-2466. 
GSA Region 9, ADP Sharing Exchange, San Francisco, CA: Feneral Services Administration (9CP), 525 Market Street, San Francisco, CA 94105. Telephone: Commercial, 415-556-7877; FTS, 556-7877.

Southern California ADP Sharing Exchange, General Services Administration (9CD-1), 880 Front Street, Room 4N22, San Diego, CA 92188. Telephone: Commercial, 714-293-5587; FTS, 895-5587.

Las Vegas ADP Sharing Exchange, Nevada Operations Office of Department of Energy (DOE), P.O Box 14100, Los Vegas, NV 89114. Telephone: Commercial, 702-734-3121; FTS, 598-3121.

Hawaii ADP Sharing Exchange, General Services Administration (9CD-2), Federal Building, Box 50011, 300 Ala Moana Blvd., Honolulu, HI 96850. Telephone: Commercial, 808-546-8636; FTS, 546-8636.

GSA Region 10, ADP Sharing Exchange, Auburn, WA: General Services Administration (10CP), GSA Center, Auburn, WA 98002. Telephone: Commercial, 206-833-6500, ext. 281; FTS, 396-5281.

Oregon ADP Sharing Exchange, Bonneville Power Administration, P.0. Box 3621, Portland, OR 97208. Telephone: Commercial, 503-234-3361; FTS, 429-4481. 


\section{APPENDIX F}

GSA SHARING EXCHANGE LOCATIONS

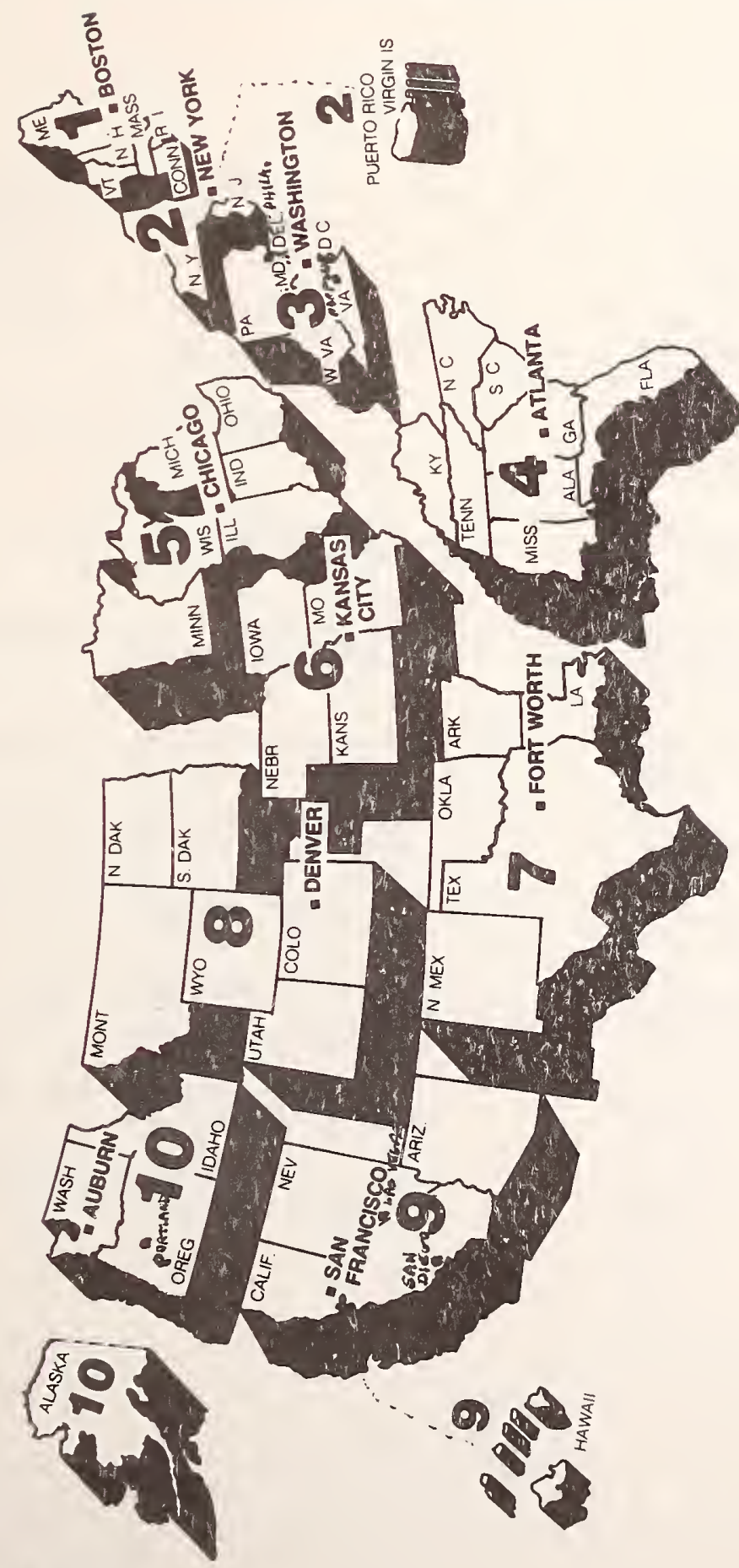





\section{GSA REGIONAL OFFICES}

\begin{tabular}{|c|c|c|c|}
\hline REGION & $\begin{array}{l}\text { OFFICE } \\
\text { PHONE }\end{array}$ & ADDRESS & AREA OF JURISDICTION \\
\hline 1 & $617-223-2735$ & $\begin{array}{l}\text { J. W. McCormack } \\
\text { Post Office \& Court House } \\
\text { Boston, MA } 02109\end{array}$ & $\begin{array}{l}\text { Maine, Vermont, New Hampshire, } \\
\text { Massachusetts, Connecticut, } \\
\text { and Rhode Island. }\end{array}$ \\
\hline 2 & $212-264-1286$ & $\begin{array}{l}26 \text { Federal Plaza } \\
\text { New York, NY } 10007\end{array}$ & $\begin{array}{l}\text { New York, New Jersey, } \\
\text { Commonwealth of Puerto Rico, } \\
\text { and the Virgin Islands. }\end{array}$ \\
\hline 3 & $202-963-6296$ & $\begin{array}{l}\text { 7th \& D Streets SW. } \\
\text { Washington, DC } 20407\end{array}$ & $\begin{array}{l}\text { Washington, D.C., Maryland, } \\
\text { Delaware, West Virginia, } \\
\text { Virginia, and Pennsylvania. }\end{array}$ \\
\hline 4 & $404-526-3000$ & $\begin{array}{l}1776 \text { Peachtree St. NW. } \\
\text { Atlanta, GA } 30309\end{array}$ & $\begin{array}{l}\text { North Carolina, South Carolina, } \\
\text { Tennessee, Florida, Mississippi, } \\
\text { Alabama, Georgia, and Kentucky. }\end{array}$ \\
\hline 5 & $312-353-5375$ & $\begin{array}{l}219 \text { South Dearborn St. } \\
\text { Chicago, IL } 60604\end{array}$ & $\begin{array}{l}\text { Illinois, Wisconsin, Michigan, } \\
\text { Indiana, Ohio, and Minnesota. }\end{array}$ \\
\hline 6 & $816-926-7555$ & $\begin{array}{l}1500 \text { East Bannister Road } \\
\text { Kansas City, MO } \quad 64131\end{array}$ & $\begin{array}{l}\text { Missouri, Kansas, lowa, and } \\
\text { Nebraska. }\end{array}$ \\
\hline 7 & $817-334-2733$ & $\begin{array}{l}819 \text { Taylor Street } \\
\text { Fort Worth, TX } 76102\end{array}$ & $\begin{array}{l}\text { Texas, Louisiana, Arkansas, } \\
\text { Oklahoma, and New Mexico. }\end{array}$ \\
\hline 8 & $303-234-2626$ & $\begin{array}{l}\text { Building 41, Denver Federal } \\
\text { Center } \\
\text { Denver, CO } 80225\end{array}$ & $\begin{array}{l}\text { Colorado, Wyoming, Utah, } \\
\text { Montana, North Dakota, and } \\
\text { South Dakota. }\end{array}$ \\
\hline 9 & $415-556-3271$ & $\begin{array}{l}525 \text { Market Street } \\
\text { San Francisco, CA } 94105\end{array}$ & $\begin{array}{l}\text { California, Nevada, Hawaii, and } \\
\text { Arizona. }\end{array}$ \\
\hline 10 & $206-833-5411$ & $\begin{array}{l}\text { GSA Center } \\
\text { Auburn, WA }\end{array}$ & $\begin{array}{l}\text { Washington, Oregon, Idaho, and } \\
\text { Alaska. }\end{array}$ \\
\hline
\end{tabular}





\begin{tabular}{|c|c|}
\hline $\begin{array}{c}\text { U.S. DEPT. OF COMM. } \\
\text { BIBLIOGRAPHIC DATA } \\
\text { SHEET }\end{array}$ & 1. PUBLICATION OR REPORT NO. \\
\hline
\end{tabular}

4. TITLE AND SUBTITLE

Guide to Technical Services and Information Sources for ADP Managers and Users

7. $A U T H O R(S)$

Shirley M. Radack

9. PERFORMING ORGANIZATION NAME AND AODRESS

NATIONAL BUREAU OF STANDARDS

DEPARTMENT OF COMMERCE

WASHINGTON, DC 20234

12. SPONSORING ORGANIZATION NAME AND COMPLETE ADDRESS (Street, City, State, zIP)
5. Publication Date

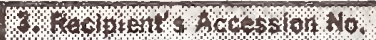
20m

F. Profinine Organization Code

8. Performing Organ. Report No.

11. Contract/Grant No.

13. Type of Report \& Period Covered

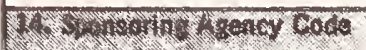

15. SUPPLEMENTARY NOTES

Document describes a computer program; SF-185, FIPS Software Summary, is attached.

16. ABSTRACT (A 200-word or less factual summary of most significant information. If document includes a signticant bibliography or lileralure survey, mention il hero.)

This puilication contains brief descriptions of technical services and resources available to Federal ADP managers and users from other agencies in the U.S. Government. The names, addresses and telephone numbers of the agencies providing computer-related services and information are included. Subject areas covered include ADP standards, reports, management, performance evaluation, training, magnetic media, software, security and technical assistance. Also included is information about Federal Information Processing Standards, Federal Standards for data communications, OMB policy guidance for ADP, procurement regulations, and GSA regional services. Federally sponsored ADP users' groups are listed. Sources are given for the documents and publications are cited.

17. KEY WORDS (six to twelve entries; alphabetical order; capitalize only the first lotter of the first key word unless a proper name, separaled by semicolons)

ADP information sources; ADP management; ADP policies; ADP services; automatic data processing; computer services; Federal Information Processing Standards; Federal standards.

18. AVAILABILITY

For Official Distribution. Do Plot Release to NTIS

Order From Sup. of Doc., U.S. Government Printing Office, Wasinington, DC 20402, SD Stock No. SNÓ03-003-

XX Order From National Technical Information Service (NTIS), Springfield, VA. 22161

\begin{tabular}{|l|l|}
\hline $\begin{array}{l}\text { 19. SECURITY CLASS } \\
\text { (THIS REPORT) }\end{array}$ & $\begin{array}{l}\text { 21. NO. OF } \\
\text { PRINTEO PAGES } \\
\text { UNCLASSIFIED }\end{array}$ \\
\hline $\begin{array}{l}\text { 20. SECURITY CLASS } \\
\text { (THIS PAGE) }\end{array}$ & 22. Price \\
UNCLASSIFIED & \\
\hline
\end{tabular}




